2017-09-22

The 'universal favourite': Daniel Terry's

Guy Mannering; or, The Gipsey's

Prophecy (1816)

\title{
Bautz, Annika
}

http://hdl.handle.net/10026.1/9978

\begin{abstract}
Yearbook of English Studies
MHRA
\end{abstract}

All content in PEARL is protected by copyright law. Author manuscripts are made available in accordance with publisher policies. Please cite only the published version using the details provided on the item record or document. In the absence of an open licence (e.g. Creative Commons), permissions for further reuse of content should be sought from the publisher or author. 


\section{The 'universal favourite,' Daniel Terry's Guy Mannering; or, The Gipsey's Prophecy (1816).}

\section{Introduction}

This essay discusses the first stage adaptation of a Walter Scott novel: Guy Mannering; or, The Gipsey's Prophecy, by Scott's friend Daniel Terry, first performed at Covent Garden in March 1816 and published in the same month. After the success of Terry's play, each of Scott's succeeding novels was adapted within months, sometimes weeks, of the novel's respective publication, for both major and

minor houses. ${ }^{2}$ Scott-based theatrical productions were so numerous in the nineteenth century that their number has been exceeded only by productions of Shakespeare. ${ }^{3}$ Critical studies of these adaptations of Scott's novels, however, are rare. There are surveys of dramatizations of Scott's works, such as H. Philip Bolton's masterly overview, or Richard Ford's catalogue, as well as accounts of some adaptations of Scott's novels, including Ann Rigney's compelling discussion of play versions of $R o b$ Roy and Ivanhoe, and David Buchanan's comparative analysis of two adaptations of The Heart of Mid-Lothian. To date, no extended study exists of the first stage adaptation of a Scott novel, Terry's Guy Mannering, or of its reception. ${ }^{4}$

In this essay, I focus on the reception of the play during the first decade after its initial performance. As well as being itself an adaptation, the play was mediated in different versions, on stage, as well as in luxury and very cheap print editions. In London, it was performed at both of the Theatres Royal, Covent Garden Theatre and Drury Lane. Terry's Guy Mannering was performed all over the United Kingdom, and widely reviewed beyond London, but these other productions are beyond the scope of this study. ${ }^{5}$ As well as gauging reception by quantifying the number of performances and discussing the kinds editions of the play text, the essay considers reviews of the play as indicators of what aspects of the drama appealed to critics and how their reactions to the play compared to responses to Scott's novel.

The purpose of this essay then is to establish a critical analysis of the reception of the play and to relate reviews of performance to those of the novel, in order to determine how the play contributed to shaping the reception of the most popular novelist of the early nineteenth century. 


\section{The novel}

Walter Scott was the most admired novelist of his time. As John O. Hayden has said, it is difficult to emphasize quite how superlative Scott's popularity was. ${ }^{6}$ His works sold in unprecedented numbers and to extraordinary critical and popular acclaim, both in Britain and abroad. His first novel, Waverley, was published in July 1814, during what the publishing world called the 'dead season', and was immediately, extraordinarily successful. The first edition of 1000 copies (already more than the 500-750 copies printed on average for novels) sold out in less than a month, and a second edition of 2000 copies had sold within weeks. Before the end of the year, the novel had gone through seven editions. ${ }^{7}$ Waverley produced unparalleled profits for its author and publisher: Constable had not been confident enough to buy the copyright outright for the $£ 1000$ Scott had demanded, so that Waverley was published on the basis of half profits - as John Gibson Lockhart, Scott's son in law, commented: 'Well might Constable regret that he had not ventured to offer $£ 1000$ for the whole copyright of Waverley!' 8

Scott's ensuing novels were even more successful. Guy Mannering; or, The Astrologer, his second novel, appeared in February 1815 in a first edition of 2,000 copies priced at a guinea. Stocks sold out on the day of publication. ${ }^{9}$ This was the first novel of the many that followed with 'by the author of Waverley' given as the authorial identification on the title page. Two further editions of Guy Mannering (hereafter abbreviated to $G M$ ) were printed in 1815, a fourth edition in 1817, a fifth and sixth edition in 1820. ${ }^{10}$ The Antiquary's first edition, in May 1816, comprised 5,000 copies, while The Heart of Mid-Lothian (July 1818) and Rob Roy (December 1817) were published in runs of 10,000 each, with the latter selling out within a fortnight of its release. The popularity of Scott's novels was superlative and led to innumerable spin-offs that included theatre versions, songs, operas, pantomimes, the circus, high and popular art, and book illustrations.

Enormous though these publication figures were, access to the novels was restricted by their price. Further to the guinea (21 shillings) required for GM, Rob Roy sold at 24 shillings and Kenilworth retailed at an unheard-of one guinea and a half (32 shillings sixpence) in $1821 .{ }^{11}$ Working-class men were earning between 9 shillings and, very exceptionally, 40 shillings a week throughout the period, ${ }^{12}$ so even where literacy was not an obstacle, members of those classes were unlikely to spend a week's wages, or more, on the latest novel. High prices meant, as Jane Austen 
lamented, that 'people are more ready to borrow \& praise, than to buy', ${ }^{13}$ but even through libraries, novels are unlikely to have reached far below middle classes: subscription or proprietary libraries charged annual fees ranging between ten shillings and two or even three guineas (and did not necessarily hold novels). ${ }^{14}$ Circulating libraries varied in price even more, depending on, for example, the size and location of the establishment, and while they often held primarily novels, this was not always the case, as David Allan has shown. ${ }^{15}$ However, the most successful circulating library in the early nineteenth century, William Lane's Minerva library, had a subscription fee of between two and five guineas in $1814,{ }^{16}$ well above a working man's means. Most of the libraries open to working-class readers were those funded by benevolent donors, and generally did not include fiction. For large sections of the population then, reading the novel on, or soon after, its publication would not have been possible.

\section{Theatres and Audiences}

Attending a performance at the theatre was much more affordable, and, importantly, did not require literacy. As David Worrall contends, 'the role of communication of audible rather than literate communication should not be underestimated' ${ }^{17}$ Ticket prices of course differed widely, but admittance to the theatre could be obtained for a fraction of the cost of access to the book. Prices for Drury Lane and Covent Garden, the only two theatres that could legitimately show drama, ranged between 1 shilling for upper gallery and 7 shillings for regular boxes (with the private boxes usually being taken by wealthy patrons for a season). ${ }^{18}$ So-called minor, or illegitimate houses offered admission from $6 \mathrm{~d} .{ }^{19}$ The Adelphi, for example, illegitimate but fashionable, charged 1 shilling for the gallery, 2 shillings for the pit, 4 shillings for a box. Until the Theatres Regulation Act was eventually passed in 1843 and finally abolished the monopoly of the patent theatres, (after more than a decade of campaigning by Edward Bulwer Lytton and others), illegitimate theatres could not officially offer the spoken word. Theatre managers and playwrights found ways around that law, however, through using song and recitative to express words, but also, by the early nineteenth century, through introducing spoken word interspersed with music. ${ }^{20}$ The forms shown at the minor theatres were therefore mainly burletta, melodrama and pantomime. Burletta in particular was drawn on as a form whose 
'great usefulness consisted in the impossibility of defining it', and, as Joseph Donohue points out, 'what cannot be defined cannot be prohibited' ${ }^{21}$

The law however reserved the 'national drama', or the unaccompanied spoken word, for the patent theatres. Plays written for performance at the patent theatres had to be submitted to the Examiner at the Lord Chamberlain's office. Few plays were rejected at that point, largely because playwrights and theatre managers would selfcensor prior to submission. The Examiner from 1778 - 1824 was John Larpent who was known to be sensitive to any references to politics, religion, and aristocratic scandals. ${ }^{22}$ As Elizabeth Inchbald noted: 'The Novelist is a free agent. He lives in a land of liberty, whilst the Dramatic Writer exists but under a despotic government. ${ }^{, 23}$ As we shall see below, Terry's Guy Mannering certainly contained nothing that Larpent could have taken exception to.

Performances at majors and minors lasted an entire evening, starting around $6 \mathrm{pm}$ and often not ending until $11 \mathrm{pm}$ or later. Both legitimate and illegitimate theatres offered half price admission to gallery and pit, usually following the first play, sometimes before the third act (of, usually, a five-act play), so that the lower classes, too, would have had access to the theatre, even if the view from the gallery was restricted. ${ }^{24}$ Guy Mannering the play was therefore accessed by far more people in a few weeks than could obtain access to the novel in a year.

At the Royal, or patent houses - Drury Lane and Covent Garden, and in the summer, when the other two were closed, the Haymarket - the gallery and pit admission prices were upheld for decades. That was famously so following the Old Price Riots of 1809, which showed how essential audiences deemed affordable admission to the national theatres, the only ones that were permitted to show drama, as a right. When the rebuilt Covent Garden reopened in 1809 after it had been burnt down, Kemble and the managers charged new, higher prices (4 shillings instead of 3 shillings $6 \mathrm{~d}$ for the pit, 7 instead of 6 shillings for the regular boxes). ${ }^{25}$ Furthermore, the restructure in favour of more private boxes meant the upper gallery was less desirable than it had previously been because of its more restricted lines of visibility. As Marc Baer contends, Kemble and the management argued within a new political economy, 'which suggested that rising costs should be met by the consumers of theatre', whereas 'many among the audience were operating within the framework of a competing "moral economy"'. ${ }^{26}$ But the audience's cry for 'old prices' was so loud and consistent that after sixty-seven nights of rioting, Kemble and the management 
capitulated. The old prices were restored (though the new prices for the boxes were retained). ${ }^{27}$

The differing prices served to uphold at least the illusion of strict class division in the theatre auditoriums. Legitimate and illegitimate theatres were built with separate entrances, while seating, too, was separate and one of the ways in which 'antagonistic relations among various segments of theatre-goers had become unmistakably clear'. ${ }^{28}$ In the new 1809 Covent Garden building, only about a third of the audience would have been accommodated in the gallery, with the much more expensive open and private boxes as well as the pit holding the greater part. And yet, as Worrall argues, 'social exclusivity or segregation of the classes was an impossibility within these spaces'. ${ }^{29}$ Most of the audience in the East End playhouses came from the immediate neighbourhood: journeymen, mechanics, shopkeepers, clerks, sailors, and women and children. But new bridges and improved transport made the East End houses more easily accessible for more affluent audiences from elsewhere in London. Famously, in the early 1820s, Queen Caroline visited Astley's, the Surrey and the Coburg theatres. ${ }^{30}$ At the legitimates, too, there was a high proportion of labourers in the audiences. Worrall's study of audience members arrested at the old price riots shows that 'Cheapside shopmen, Hackney coal merchants, footmen in livery, Shadwell brewer's clerks, a Soho "respectable tradesman" and a journeyman courier' were among the audience, as well as 'a Smithfield oil and colourman, a hairdresser, two silver-spoon makers, a major in the army'. ${ }^{31}$ Worral points out that these theatres, 'like their mirror images the churches reached audiences drawn from all the social classes, ${ }^{32}$ and enabled the mixing of social classes in the same space.

The differences between the social classes of theatre goers also manifested themselves in the kinds of productions that were favoured. Theatre managers had on the one hand to please the 'wealthy patrons who might reserve a box for the season', but at the same time, and for the same performances, they also had to attract spectators from much lower down the social scale. ${ }^{33}$ Entertainments were varied, and the legitimate houses put on an increasing number of the more vocal productions that were shown at the illegitimates; burletta and melodrama. ${ }^{34}$ In Jeffrey Cox's words, in terms of productions, 'there was more traffic between 'legitimate' and 'illegitimate' theaters than the law imagined'. ${ }^{35}$ The competition between major and minor houses intensified as they increasingly vied for the same audiences. Furthermore, the new 
Covent Garden and Drury Lane buildings were so vast that straight plays were difficult to put on as large sections of the audience would not be able to hear the spoken word. Consequently, plays written for performance at the patent theatres increasingly contained a high proportion of sung words, and one of the most popular examples of a musical play of the period was Guy Mannering.

\section{Daniel Terry's Guy Mannering; or, The Gipsey's Prophecy: performances and audiences.}

Guy Mannering; or, The Gipsey's Prophecy: a Musical Play in three acts, by Daniel Terry, Esq., of the Theatre-Royal, Covent-Garden, was first performed on 12 March 1816, just over a year after the publication of Scott's novel in February 1815. The play established a precedent for stage adaptations of Scott's prose fiction, largely because, from the first night onwards, it was immensely popular. Many other Scott adaptations followed, including other versions of Guy Mannering, but none of the rival versions came close to Terry's in popularity, and most were derived from his. ${ }^{36}$ Terry was said to have 'absolutely netted the immense sum of thirteen-hundred pounds by his operatic version of Sir Walter Scott's "Guy Mannering", 37 Scott had advised Terry on the script, and in the following years sent him proofs of his novels to give him a head start over other playwrights who would rush to produce an adaptation of the latest Scott novel. ${ }^{38}$ Reviewers attribute the play's popularity partly to it being an adaptation of one of the most popular novels of the age, expecting the 'celebrated title, bestowed for the first time upon a musical drama, [to] draw after it a crowded house'. ${ }^{39}$ It was then shown in every season from 1815-16 to 1823-24, and in these 9 year was performed at least 93 times at Covent Garden, ${ }^{40}$ beside being shown at Drury Lane and elsewhere, in London. Within weeks it was performed all over the United Kingdom, as well as abroad, repeatedly drawing 'one of the most crowded audiences of the season'. ${ }^{41}$ While the novel's fame fed into the play's popularity, the play also enhanced the novel's popularity and the life of its characters.

Not only did contemporary reviewers comment on its extraordinary popularity at the time, but critics decades later still discuss the longevity and enduring popularity of this play. For example, a memoir of Terry published in 1827 states: 
If, too, popularity is a test of excellence, Guy Mannering stands in the first rank; for no drama has been a more universal favourite; it has been adapted by both our regular stages, and played in almost every theatre throughout the country; indeed we much doubt if a single exception can be found. This is no light praise, and to this, in its utmost extent, the author of Guy Mannering is truly and honourably entitled. ${ }^{42}$

At the time Terry's Guy Mannering was first performed, the capacity of Drury Lane and Covent Garden was 3100 and 3000 respectively. ${ }^{43}$ In the 93 Covent Garden performances over the first 9 years following the first production of Terry's Guy Mannering on stage alone, even if we assume the house not full to capacity - and it must have been fairly full for the play to be put on this frequently - the audience figures will have been at least 250,000, likely higher. This dwarfs the readership of Scott's novel based on publication figures; even if we assume many readers for each copy of the book, just the Covent Garden audience of Guy Mannering the play in these nine years is likely to have been at least five times higher than the readership of the novel in the whole kingdom for the same period. And Terry's play was put on in theatres throughout the country, so that overall, many more people would have encountered the staged versions of Terry's Meg Merrilies, Guy Mannering, Lucy Bertram and Dominie Sampson, than Scott's.

\section{The play's text.}

The text of the play was printed in 1816 and would likely have been available to buy in the theatre (and elsewhere) from the first performance onwards. It was published by Miller retailing at 2s $6 \mathrm{~d}$, so a fraction of the price of the novel; by 1817 the text stated on its title page that it was in its third edition, by 1818 in its fourth. Terry's Guy Mannering was the version that featured in the numerous collections of the Waverley Dramas, because, unlike some other Scott plays where there were competing adaptations, Terry's, as the first adaptation of any Scott novel, continued by far the most dominant, with 'virtually no other English versions ... ever published'. ${ }^{44}$ The play became part of standard collections of British plays, such as William Oxberry's New English Drama (1818), and held its place in the canon, being included in collections such as Cumberland's British Theatre of 1843, or John Dicks' - 
innovative because extraordinarily cheap - illustrated one-penny series of The British Drama (1864).

Not surprisingly, Terry introduced some changes to plot and characters in his rendering of the novel for the stage, such as reducing the number of characters and collapsing time. Julia Mannering becomes Guy Mannering's sister, not daughter, and Lucy Bertram ends up marrying Guy himself. Charles and his father Sir Robert Hazlewood can therefore be written out of the drama. One of the effects of the Lucy and Guy love interest is to render Lucy more conservative even than she is in the novel. She is presented as a passive model of propriety and needs Guy Mannering's protection from the start, then to marry the man in whose house she lives, who was her father's friend, and who acts as her guardian. While his gallant behaviour to Lucy Bertram is noticeable from the start, as well as her proper response, from the beginning of Act 2 Julia Mannering makes clear that his gallantry is more than disinterested: 'A lion in the toils! Oh, Lucy, dear Lucy! If you knew what meshes have been spread for that proud Colonel, in vain. ${ }^{45}$ Lucy gives voice to her feelings in a song to Julia that proves her to be a model of propriety:

Air. [Miss Bertram.]

Oh! Blame me not, that such high worth

Hath rais'd of love the gentle flame;

Yet, as I own it - quicker throbs

The timid, trembling pulse of shame.

When pity dries the falling tear,

Love, unperceiv'd, will venture in;

And kindness to a wounded heart,

Is sure that wounded heart to win.

My faultering tongue, my downcast eyes,

Reveal my bosom's thoughts too plain;

But where love wore a form so good,

Ah! Tell me, could it plead in vain?

This heart, without a resting place, 
Was like the wandr'ing weary dove,

Return'd from sorrow's storms, to seek

A shelter in the ark of love. ${ }^{46}$

Many of the songs from the play became popular as stand-alone pieces. The sheet music could be bought immediately, and songs were included in collections, offering additional channels through which Scott's characters would have been known and taken shape. ${ }^{47}$ In this case, the song emphasizes Lucy as having fallen in love with the hero in a way stereotypical heroines of the period's conservative novels do, in line with conduct manuals: unintended, unperceived, ashamed of the - gentle - emotion once realized, as a response to being loved by an older kind man, and in need of protection and guidance. The double wedding at the end just after Meg's dramatic death also of course is a more easily pleasing scene than the eponymous hero's single state at the end of the novel.

To make Julia Guy's sister rather than daughter on the one hand collapses time, and on the other makes it possible for her to banter with Mannering throughout in a way a sister might. It also perhaps renders her disobedience to Mannering in her relationship with Captain Brown (alias Henry Bertram) a little less exceptionable. The play allows her to give in to a reluctant meeting with Brown as her lover, although this soon turns into a comic hide-and-seek scene where first Sampson and then Mannering himself enter the room and Brown has to hide in various places before he can escape, while Flora and Julia have to make excuses for noises and other evidence. After Brown's escape, she reflects:

I declare I am frightened at my own imprudence! Should my brother discover this business, what will be the consequence? Oh, dear! I wish he would but sympathise a little more with love, and a little less with honour - but alas! $!^{48}$

While she is imprudent here by talking to her lover in her boudoir at midnight, her servant Flora is always present and Julia has neither arranged nor sanctioned the interview, although she does then conceal Brown's presence from her brother. Julia does not venture beyond reluctant verbal replies, so that honour and gender boundaries can be upheld, and in the end love and honour can be combined because Brown turns out to be Bertram, the heir to the estate of Ellangowan. 
While there are fewer characters in the play than in the novel, there are still characters from various social classes, and while the main focus is on the four lovers, Meg Merrilies, Dandie Dinmont, Dominie Sampson, other gipsies and minor character such as Mrs MacCandlish the innkeeper, are of significant interest and importance, which, given the mixed-class audiences at the theatres, may have contributed to the broad appeal the play enjoyed for many years. Meg in particular is given significance, partly by being in the subtitle - 'The Gipsy's Prophecy', as compared to the novel's subtitle of 'The Astrologer' - but also by the climax centring on the heroic death that she goes to knowingly in order to save Harry Bertram's life and reinstate him as heir. Perhaps to keep her as a character apart from the others, she and Guy Mannering, the hero and older lover, are the only main characters who are not given a song (where she has verse in the play the directions specify 'Meg speaks', not sings).

The prophecy itself has also been changed. While both Guy Mannering and Meg predict little Harry's future in the novel, in the play, neither does. Guy Mannering is told the story of Harry's loss at the beginning of Act 1, when he arrives in a Scottish inn after many years' absence in India. He 'heard [old Bertram] had a son', ${ }^{49}$ but he has not seen him, let alone predicted the boy's future. His connection to the Bertram household is older; he describes old Bertram as 'my earliest, and best friend'. ${ }^{50}$ The backstory is therefore altered, with Guy listening to the narration of the innkeeper, and Meg barely featuring in it. Meg's prophecy is in fact about herself, as the saviour of Harry Bertram and the House of Ellangowan, as she makes clear in Act 3:

Now then, to complete the work of Fate, tho' every step I take be on a corpse. I was born to raise the old House of Ellangowan from its ruins - and the moment is at hand when all shall behold -

Bertram's right, and Bertram's might, Meet on Ellangowan's height. ${ }^{51}$

In the play then, the only person who has powers to see the future is a Scottish gipsy, not a rational English gentleman.

Overall then, and whether for dramatic effect or driven by ideology or politics, the changes made to the novel in Terry's adaptation have the effect of making the plot 
and the characters more conservative, particularly in terms of gender. Terry's Guy Mannering as staged and printed therefore contains nothing that any member of the audience or the Examiner at the Lord Chamberlain's office could take exception to. None of the middle-class characters are seen to overstep boundaries. At the same time however, Meg is not held to rules of either propriety or realism so that the outlandishness, power and pathos of the novel's Scottish gipsy is preserved in the play.

\section{Upmarket and Abridged Versions.}

The various early editions of the play text of Guy Mannering are a good indication of its popularity. Some editions of the play text were more upmarket, and included prefatory remarks and images, such as Oxberry's New English Drama Series, in which Guy Mannering was included in volume 12 (1818, then reprinted several times) as the first of five plays in that volume, followed by Cymbeline, Twelfth Night, The Confederacy (by Sir John Vanbrugh, first performed in 1705) and Douglas (the 1755 tragedy by John Home that had also been popular for many years). To be included alongside four plays that had all acquired the status of classics - two Shakespeare plays, and two other well-known plays that had both been performed for decades emphasizes the high level Terry's Guy Mannering is placed on. Each play in Oxberry's edition was headed by a frontispiece of a famous actor playing one of the characters. In the case of Guy Mannering, the frontispiece shows Mr Liston as Dominie Sampson, the faithful but comic schoolmaster companion to Lucy Bertram, a choice that emphasizes the importance of the characters that may seem marginal to the plot but are central to how the play (and the novel) is received.

The introductory remarks give biographical information about Terry as a 'master' dramatist, which again emphasizes the play's status as its author is someone the reader should be interested in. The introduction discusses Guy Mannering's genre as 'a very near kinsman of the melodrama' and recognizes that this kind of play is now 'infinitely more popular than any classical composition'. ${ }^{52}$ However, the author cannot be blamed for this shift in audience taste, and instead needs to be praised for the skilful way in which he has adapted the novel into a play. While there is a recognition that the drama performed at the patent theatres is increasingly similar to 
that performed at the minors, the emphasis is still on the quality of this particular play, even as a melodrama. Oxberry's edition must also have been intended to be used for amateur performance as it gives exact stage directions, costume instructions, timings, and positioning of characters. This again shows how well-regarded and popular the play was.

Alongside these editions of Terry's play retailing at $2 \mathrm{~s} 6 \mathrm{~d}$ or above, there were cheaper, abridged versions, down to a penny dreadful. ${ }^{53}$ William Hodgson, for example, brought out an abridged version of Terry's Guy Mannering in 1822 in his company's Juvenile Drama series. This edition was edited to fit 24 pages, so consisted of two sheets, and was priced at sixpence, which was much more affordable than Miller's edition of Terry's text, and also, of course, cost a fraction of the price of the novel. Hodgson had even entered his edition at the Sationers' Hall and the Stamp Office to give the text more authority.

Presumably to protect himself from piracy charges, Hodgson changed the words of Terry's text, though not the meaning of the sentences, or the characters. For example, the question of Mrs MacCandlish, the innkeeper, to Colonel Mannering in the original, 'I beg your Honour's pardon. Would your Honour choose any refreshment after your ride?' is changed to 'Will your Honour take anything?'. ${ }^{54}$ Similarly, Meg's working on Harry Bertram to remember who he is, is altered. In Terry's original Meg says: 'Hark! Hark! To the sound of other days! Listen, and let your heart awake.', and the song she used to sing for Harry when he was an infant and now asks the gipsy girl to sing starts: 'Oh! Slumber, my darling...' ${ }^{55}$ In Hodgson's version this reads: 'Hear what I say, let your whole soul attend to me.' The song starts: 'Oh, sleep on my infant. ${ }^{56}$ Not only are these passages abridged in Hodgson's version, but the words are also carefully replaced by synonyms while the meaning is retained.

The play of Guy Mannering entered the market at various levels, as a performance, as an official play text, as a text that would be used for private theatricals, and in cheaper versions that could be had for sixpence.

\section{Reviews of the novel and the play}

While print runs, runs of performances, numbers and kinds of editions, prices of texts and theatre tickets give indications about popularity, they do not tell us what about the 
novel and the play appealed (or otherwise) to readers and audiences. This essay focuses on reviewers' opinions as recorded in contemporary periodicals, so it is beyond the study's scope to consider other kinds of reception such as more popular opinions recorded in diaries and letters. While reviews are not necessarily representative of a more popular reception, they give an indication of how some contemporaries reacted, and crucially, they show how critical opinions of novel and play compare.

The early nineteenth century was the heyday of periodical criticism. As William Hazlitt wrote in The Edinburgh Review in 1823, "We are nothing, if not critical" Be it so: but let us be critical, or we shall be nothing. ${ }^{, 57}$ Over 60 periodicals carried reviews of literary texts and theatrical performances in the early nineteenth century. Reviews were usually anonymous, using a corporate 'we', which was supposed to make criticism more easily possible. Theatrical reviewing in particular changed significantly during the period: while reviewers of performances had been regarded as 'puffs' in the late eighteenth and very early nineteenth centuries, who were offered payments or free seats in exchange for positive reviews, this practice was being replaced by what Jeffrey Cox and Michael Gamer describe as 'some of the most perceptive criticism the theatre has ever received' ${ }^{58}$

Reviews of novels, too, were not always highly regarded, largely because of fiction's low status. As Ina Ferris points out, reviews and novels were each 'a borderline discourse, neither fully literary nor fully commercial ${ }^{59}$ Many reviewing periodicals therefore carried no, or only very few, reviews of new novels. For a novel to be reviewed at all was already a significant achievement. However, Scott's novels were all reviewed, in several periodicals, and often in long articles. The next section briefly outlines responses to Guy Mannering the novel as recorded in reviews. Relating reviews of the play to those of the novel makes it possible to identify which aspects of the story appealed more broadly, and which were specific to the play. Scott's second novel appeared in February 1815 and, like Waverley, was noticed by many more reviewing periodicals than an average novel would have been. Though the overall verdicts on Guy Mannering are generally positive, the majority of reviews also include criticism. Criticism tends to centre on the way romance and realism are combined in the novel's use of astrology. Both Meg Merrilies and Guy Mannering predict Harry Bertram's fate, but it is only to Mannering's involvement that reviewers take exception to. Mannering as an Oxford scholar of the late eighteenth century is 
well within reviewers' knowledge, even experience, and is therefore a figure of realism that they expect to act in a way they can recognize and approve of. That he should make use of astrology is a 'monstrous absurdity': ${ }^{60}$ he can have contact with the world of romance by travelling to Scotland, the land of romance, but he has to behave there, as everywhere, in accordance with his origin and time. ${ }^{61}$

Meg also predicts the future. Reviewers deem this acceptable behaviour on her part: she is a figure of romance, and modes of behaviour belonging to that cast are therefore consistent with her character. As a Scottish gipsy matriarch she is exotic, and her actions and manners represent 'a class of people formerly so common in [Scotland]'. ${ }^{62}$ Like ordinary characters of romance she is fictitious, but in contrast to them she represents a class of people that once existed. The novel is set in the past, albeit a very recent past, and Meg is a gipsy as well as Scottish, so that she is removed on several counts from an English readership. Her exoticism and her romantic quality render the image the novel draws of her a realistic one: her dealings 'may be true to nature, as the Scotch have not yet thrown off their belief in witchcraft, and continue bigots to the influence of second sight ${ }^{63}$ Meg believing in the power of astrology is acceptable because it does not deprive her of realism: what is a 'monstrous absurdity' in an Englishman forty years ago is 'true to nature' in a female Scottish gipsy of the same period.

Reviewers were drawn to Meg because she operates in a different set of beliefs from their own and could thus be seen as an original type of character. In the delineation of the more familiar characters - Guy Mannering, Harry Bertram, Charles Hazlewood, Julia Mannering, Lucy Bertram - 'there is nothing very original or happy, ${ }^{64}$ and these are regarded as 'very little above the cast of a common lively novel'. ${ }^{65}$ It is therefore the inclusion of romantic characters that contributes to elevating the work above common novels, yet reviewers insist on this romance being clearly separated from their mode of life and are keen to emphasize the differences between Meg's Scottish, gipsy world and their own.

Reviews of Guy Mannering emphasize Scott's eminent position, even though the novel was published without his name. The most important criterion in assessments of other contemporary novels is moral instruction. ${ }^{66}$ In articles on Guy Mannering, instruction does not feature at all and the work is criticized on moral grounds, as some readers might be induced by the author's skilful depiction of astrology to believe in its powers, so that its realistic representation in the novel poses 
a moral threat. In fact, 'the moral might [in history] have subjected the printer to an indictment for supporting astrology and witchcraft ${ }^{67}$ A potentially dangerous moral message would have meant, for most ordinary novels, an overall negative verdict. Instead, reviewers praise Guy Mannering in spite of its potentially harmful influence, which testifies to the extraordinary status of a work by the author of Waverley. Scott's works are thus not judged within the novel genre but in a class apart, and this extraordinary level of admiration filters through to reviews of Terry's adaptation of the novel into a musical play.

\section{Reviews of the Play}

Reviews of the play were overwhelmingly positive, and emphasize its favourable reception by the audience: 'the general effect of the Opera was so superior, that its announcement for repetition this evening was received with tumultuous probation by the audience ${ }^{68}$ On the whole, reviews show a similar emphasis to those of the novel, though they also of course make room for the discussion of individual performers. As in reviews of the novel, the focus is on Meg, the Scottish gipsy, and the performance of the actor playing her. Reviewers applaud the successful blend of 'the terrific and the affecting', with the display of her 'extreme emotion [making] the character appropriately dominant'. ${ }^{69}$

Particularly the very early reviews however, while they also praise the play, are clear that the performance of the adaptation can never reach the quality of the novel. As already mentioned, Terry's Guy Mannering was the first stage adaptation of any Scott novel, and for the early reviewers the novel dominates so that the play is always judged against it. A review of Terry's Guy Mannering published the day after the opening of the play on 12 March 1816 at Covent Garden still struggles to come to terms with the idea of adapting a novel by the Wizard of the North for the stage at all:

scarcely any degree of skill in the adaptation of it to the stage, or of genius in the principal actors, could transfer to the play even a faint resemblance to that fervid and ungovernable interest which agitates us through so many pages of history itself. ${ }^{70}$

As is typical of reviews of Scott, his novels are seen as being in a league of their own, and are therefore also deemed above adaptation. This is perhaps particularly evident 
in the discussion of Meg: while Sarah Egerton played the part of Meg 'with considerable ability and feeling', it was impossible, even for her, 'to embody in ordinary mortal form, and to give expression through human organs to the spirit of that indefinable being, tinged with melancholy, clothed with fierce grandeur, and breathing prophecy'. ${ }^{71}$ Other early reviewers' comments are similar in not blaming Mrs Egerton for what they perceive as a relative failure, but the sheer impossibility of rendering Scott's character on stage:

Mrs Egerton's Meg Merilies [sic] possesses great vigour without surpassing nature; and this is all we have a right to expect from the actress. Still, in the prophetess, we look for the wildly rolling eye of superhuman agency, [a voice] which approaches sublimity, and invests the character with awful grandeur. ${ }^{72}$

The play is as good an adaptation as possible, and the acting, too, could not humanly be better, and yet for Meg, this is insufficient because she needs to be more than human to reach Scott's Meg.

For all reviewers of the play, following the novel closely makes the play superior because the novel's status as superlative is never questioned; in fact, 'in the novel from whence the plot is taken, [Terry] found the characters already dramatised', but the adapting he had to do he executed "with a considerable degree of acuteness and discrimination'. ${ }^{73}$ Reviewers found 'the dialogue extremely well written'. ${ }^{74}$ Closeness to the novel also means reviews do not need to take up 'our readers' time in detailing [the plot] $]^{75}$ as 'the novel from which the story is taken is ... generally known', ${ }^{76}$ expecting the audience, or rather, those among the audience who are likely to read a review, to be familiar with the novel. This assumption implies that the closer the play and the acting are to the novel, the more superior they will be.

Over the ensuing years, all of Scott's novels were adapted for the stage, often within days or weeks of publication of the novel. Reviewers, more used to the idea of Scott adaptations, therefore make explicit references back to the novel less frequently. Even later reviews however, which discuss the play less and the acting more as the element that is new, bestow the highest praise when acting is as close as possible to the characters in the novel. For example, Miss Byrne's performance as Julia Mannering is 
described as having 'raised the character to a rank it had not before attained in the opera. Her style of acting, and even of dressing the part, reminded us more strongly of the novel than any previous representation of the play', ${ }^{77}$ and so, by implication, was superior to any previous rendition. Similarly, because 'Miss Povey's Julia Mannering was not that of the novelist', she was not among the best actors that night. ${ }^{78}$

Generally, the actors employed were the period's first-rate, well-known actors. They were usually cast as a character in the play for a season and beyond, and made the character their own, for example through the inclusion of songs that are not in Terry's play text. The songs chosen often have a loose and sometimes no immediate connection to the plot of the play. For example, John Braham, who played Henry Bertram at both Covent Garden and Drury Lane for several seasons, added ballads such as, 'Scots wha hae wi' Wallace bled', 'Bruce's Address to his Army', and 'The last words of Marmion'. ${ }^{79}$ This choice of songs emphasizes the drama's cultural 'Scottishness' and historicity as well as the Scott connection, all of which reviewers remark upon. ${ }^{80}$ The interspersed songs further stressed the difference between the lives of the audience and that of the characters on stage, as well as the celebrity status that the author of Waverley's name brought, but they also became a means for the actor to render his or her version of the character distinct.

Connected to the focus on Meg as the most exciting and different character are comments on the qualities of the other female characters. Just as reviews of the novel accept Meg to be outlandish and a prophetess, but not Guy Mannering because he falls into their experience as an English gentleman, reviewers of the play accept Meg as different because she is Scottish and a gipsy while expecting the other women to be acted in 'chaste' and 'sweet' ways. ${ }^{81}$ In particular, Lucy Bertram is perceived as a stereotypically helpless and conservative model of heroine in the play, and reviewers want her to be acted as such. Maria Tree's rendering of Lucy Bertram is commended because of her 'modest propriety, a natural and touching simplicity of manners, which powerfully interested the audience'. ${ }^{82}$ Similarly, 'the sweetness and simplicity of Miss Carew' as Lucy Bertram is admired, whereas Mrs Gibbs as Flora 'requires the severest reprobation $[\ldots]$ by a disgusting indecency of dress' ${ }^{83}$

Importantly then, acting at the Theatres Royal, especially female acting, was expected to be respectable, on and off stage. Catherine Stephens, the Lucy of the first performance, is highly celebrated in all reviews, again for the 'sweetness and simplicity' of her acting and singing. ${ }^{84}$ Judith Pascoe's words on Sarah Siddons' 
influence, who, 'in character roles and in the role of respectable matron, served as an enabling model for other women looking for ways to enter the public sphere without damaging their personal reputations in the process', 85 might perhaps be applied to Stephens: in her private life, she became Countess Dowager of Essex. ${ }^{86}$ Similar to how reviewers comment on Miss Stephen’s performances, Miss Carew’s 'chaste acting', too, is commended, ${ }^{87}$ and an unnamed young lady who 'made her first appearance in the arduous character of Lucy Bertram [evidently] has the manners of a gentlewoman'. ${ }^{88}$ For reviewers, it is only Meg who is allowed to be unconventional and unbound by the rules of female propriety because she is a Scottish gipsy, so twice removed from reviewers' own lives, whereas the daughter of the English gentleman has to display chastity, sweetness and simplicity, perhaps especially on stage. ${ }^{89}$ Overall, both the play and the 'actors of first-rate talent' contribute 'to preserve unsullied the high character of British drama'. 90

\section{Conclusion}

This exploration of the first stage adaptation of a Scott novel and its reception has shown four things: firstly, at Covent Garden alone, many more people saw Terry's version of Guy Mannering between 1816 and 1824 than would have read the novel across the whole kingdom during the same period. Many contemporaries would therefore have become familiar with the play's characters as given by actors and as presented in both Terry's version and abridgements of it. Secondly, Terry's adaptation renders the novel more conservative, for example in its representation of issues relating to gender. Lucy Bertram is passive in Scott's novel, too, but this is taken to extremes in the play and reviewers expected actresses to present the character in 'chaste' ways. Thirdly, reviewers' - and the audiences' - reactions to the first stage adaptation of a Scott novel were largely positive. They interpreted the play as 'complimentary to the taste and study of Mr Terry', 91 partly because they believed him to have kept closely to the novel. Fourthly, reviews of the play on the whole discuss similar points to those raised in reviews of the novel. A crucial difference is that Guy Mannering does not predict the future in the play so that the main point of criticism in reviews of the novels does not apply to reviews of the play.

While the novel informed the reception of the play, the play also contributed to enhancing the novel's popularity. Anastasia Nikopoulou claims that 'Scott's popularity was increased by staging of his works rather than the other way around'. ${ }^{92}$ 
However, regarding Terry's Guy Mannering, this essay has demonstrated that popularity of play and novel fed each other: on the one hand, the play made plot and characters (albeit its version of them) accessible to a much wider socio-economic group and much sooner than editions of the novel did, but on the other, reviews show that the play's popularity was enhanced by Scott's extraordinary fame and status, and indeed, was judged by its closeness to the novel. Terry's play paved the way for a plethora of stage adaptations of Scott's novels, and presents one of the many spin-offs that Scott's works inspired and enabled. The play, in turn, contributed to shaping the reception of the most popular novelist of the early nineteenth century. ${ }^{93}$

Annika Bautz

Plymouth University

Notes

${ }^{1}$ William Oxberry, 'Memoir of Mr D. Terry', in Oxberry's Dramatic Biography and Histrionic Anecdotes, Jan 1827, p7.

${ }^{2}$ As Barbara Bell emphasizes, Scott novels were turned into 'whatever type of play, musical play, drama, operatic drama, opera, burletta, melodrama, burlesque, or pantomime might be required for [theatre managements'] particular situation'. 'The Performance of Victorian Medievalism', in Beyond Arthurian Romances: The Reach of Victorian Medievalism, ed. by Jennifer Palmgren and Lorretta Holloway (Basingstoke: Palgrave Macmillan, 2005), pp. 191-216, p. 213.

${ }^{3}$ Ann Rigney, The Afterlives of Walter Scott: Memory on the Move (Oxford University Press, 2012), p. 60. Also see for example William Knight's account of the Surrey Theatre: here, and elsewhere, Scott adaptations were 'all the rage'. William Knight, A Major London 'Minor': The Surrey Theatre, 1805-1865 (London: The Society for Theatre Research, 1997), p. 34. Some overviews of theatre in the nineteenth century do not mention Scott adaptations at all; for example, The Performing Century: Nineteenth-Century Theatre's History, ed. by Tracy Davis and Peter Holland (Palgrave 2007).

${ }^{4}$ H. Philip Bolton, Scott Dramatized (London: Mansell, 1992); Richard Ford, Dramatisations of Scott's Novels: a Catalogue (Oxford: Bibliographical Society, 1979); Ann Rigney, The Afterlives of Walter Scott, David Buchanan, 'Popular Reception by Dramatic Adaptation: The Case of Walter Scott's The Heart of MidLothian', European Romantic Review, 22. 6 (2011), 747-65.

${ }^{5}$ For the popularity of Scott adaptations particularly in Scotland, as 'National Dramas', see for example Barbara Bell, 'The National Drama', Theatre Research International, 17.2 (1992), 96-108.

${ }^{6}$ John O. Hayden, ed., Scott: The Critical Heritage (London: Routledge, 1970), p. 1. 
${ }^{7}$ Editions according to title page; four of these were not new editions in a bibliographical sense but reissues. (Annika Bautz, The Reception of Jane Austen and Walter Scott (London: Continuum 2007), p. 23; William Todd and Ann Bowden, Sir Walter Scott: a Bibliographical History, 1796-1832 (New Castle, DE: Oak Knoll, 1998), pp. 309-16.

${ }^{8}$ J. G. Lockhart, Memoirs of the Life of Sir Walter Scott, Bart., 7 vols (Edinburgh: Robert Cadell; London: John Murray, 1837), III, p. 296.

${ }^{9}$ Bautz, The Reception of Jane Austen and Walter Scott, p. 31.

${ }^{10}$ William Todd and Ann Bowden, Sir Walter Scott: a Bibliographical History, 17961832 (New Castle, DE: Oak Knoll, 1998), pp. 361-68.

${ }^{11}$ Todd and Bowden, p. 537. HOM retailed at 32 shillings because it contained 4 volumes rather than the usual 3.

${ }^{12}$ Kathryn Sutherland, ''Events... have made us a world of readers': 'Reader relations' 1780-1830', in The Romantic Period, ed. by David B. Pirie (London: Penguin, 1994), pp. 1-48, p. 9.

${ }^{13}$ Jane Austen, letter to Fanny Knight, November 1814; in Jane Austen's Letters, ed. and coll. by Deidre Le Faye (Oxford: Oxford University Press, 1995), p. 287.

${ }^{14}$ Plymouth Public Library charged three guineas (Laws of the Plymouth Public Library, and Catalogue of the Books, Maps, Newspapers, \&c. Plymouth: 1824, p. xi). See also Thomas Kelly, Early Public Libraries (London: The Library Association, 1966), p. 128. The annual subscription around 1800 is about 'ten shillings or more'; William St Clair, The Reading Nation in the Romantic Period (Cambridge University Press: 2004), pp. 667-68. Hull Subscription Library charged one guinea annually in 1820, and York Subscription Library charged one guinea in 1794. Selkirk Subscription Library allowed nonmembers access for half a guinea annually See Mark Towsey, "Store their Minds with Much valuable Knowledge": Agricultural Improvement at the Selkirk Subscription Library, 1799-1814', Journal for Eighteenth-Century Studies, 38.4 (2015), 569-82, 571).

${ }^{15}$ Allan emphasizes the variety of circulating libraries: some indeed primarily held novels, but the surviving catalogues of others suggest that only a small percentage of the stock was fiction. David Allan, A Nation of Readers; the Lending Library in Georgian England (London: British Library, 2008), pp. 134-39.

${ }^{16}$ Sutherland, p. 12.

${ }^{17}$ David Worrall, Theatric Revolution: Drama, Censorship and Romantic Period Subcultures 1773-1832 (Oxford: OUP, 2008), p. 274.

${ }_{18}$ Marc Baer, Theatre and Disorder in Late Georgian London (Oxford: OUP 1992), p. 22.

${ }^{19}$ Joseph Donohue, 'Theatres, their architecture and their audiences' in The Cambridge History of British Theatre, Vol. 2, 1660-1895, ed. by Joseph Donohue (Cambridge: Cambridge University Press, 2004), pp. 292-308, p. 295.

${ }^{20}$ Joseph Donohue, 'Burletta and the early nineteenth-century English Theatre' in: Nineteenth-Century Theatre Research (1973), pp. 29-51, p. 43.

${ }^{21}$ Donohue, 'Burletta and the early nineteenth-century English Theatre,' p. 30.

22 Jeffrey Cox, 'Re-viewing Romantic Drama', Literature Compass, 1 (2004), p. 9; Worrall, Theatric Revolution, esp. pp. 104-32.

${ }^{23}$ Elizabeth Inchbald, 'To The Artist', [The Artist, No. xiv, $13^{\text {th }}$ June 1807], cited from Appendix to Inchbald, Nature and Art, ed. S. Maurer (London: Pickering and Chatto, 1997), p. 143. 
${ }^{24}$ Frederick Burwick, British Drama of the Industrial Revolution (Cambridge:

Cambridge University Press 2015), p. 6; Baer, p. 30.

${ }^{25}$ Baer, p. 22.

${ }^{26}$ Baer, p. 22.

${ }^{27}$ Baer, p. 36.

${ }^{28}$ Donohue p. 225.

${ }^{29}$ Worrall, p. 229.

${ }^{30}$ Jane Moody, Illegitimate Theatre in London, 1770-1840 (Cambridge: CUP 2000), pp. 165 ff; Worrall, pp. 196 ff.

${ }^{31}$ Worrall, pp. 228-29.

${ }^{32}$ Worrall, p. 274.

${ }^{33}$ Burwick, p. 6.

${ }^{34}$ Donohue pp. 224. Jane Moody describes Burletta as 'strict musical pieces without dialogue, usually in three acts and containing about six songs' (Illegitimate Theatre, p.6).

${ }^{35}$ Jeffrey Cox, p .9.

${ }^{36}$ Bolton, p. 57. Notably among early versions are J.R. Planche's 'The Witch of Derncleugh' (1821), and Douglas Jerrold's 'The Gipsy of Derncleugh' (1821).

${ }^{37}$ Oxberry, p. 7.

${ }^{38}$ Peter Garside points out that Scott thought about including a song from Joanna Baillie's play Orra: A Tragedy in Guy Mannering. See Walter Scott, Guy Mannering, ed. Peter Garside (Edinburgh: University Press, 1999), p. 543. Terry has the gipsies sing the song in Act 2 Scene 3 (Daniel Terry, Guy Mannering, or, The Gipsey's Prophecy: A Musical Play in Three Acts (London: Miller, 1818)). Philip Cox shows how Scott helped Terry in the race to get a play version out by sending him proofs of his next novel. See Philip Cox, Reading Adaptations: Novels and Verse Narratives on Stage, 1790-1840 (Manchester University Press, 2000), p. 80.

${ }^{39}$ The Times, $13^{\text {th }}$ March 1816, p. 3.

${ }^{40}$ Bolton, p. 56.

${ }^{41}$ The Times, 3 December, 1817, p. 2.

${ }^{42}$ Oxberry, pp. 7-8.

${ }^{43}$ Jeffrey Cox 'Re-viewing Romantic Drama' in: Literature Compass 1 (2004), pp. 127, p. 9-10; Joseph Donohue, 'The theatre from 1800-1895', in The Cambridge History of British Theatre, Vol. 2, 1660-1895, p. 224. The new Covent Garden Theatre held more than 2800 private boxes.

${ }^{44}$ Bolton, p. 56-7.

${ }^{45}$ Terry, GM (Miller: 1818), Act 2, Scene 1, p. 25.

${ }^{46}$ Terry, GM (Miller: 1818), Act 3, Scene 1, p. 49.

${ }^{47}$ For example, 'Oh! Rest thee babe', sung in Guy Mannering, written by D. Terry, Esq., Music by John Whitaker (London: C. Sheard, c1820), or, for a collection: The Universal Songsters; or, Museum of Mirth: forming the most complete, extensive, and valuable collection of ancient and modern songs (London: Jones, 1829).

${ }^{48}$ Terry, GM (Miller: 1818), Act 2, scene 1, p. 32.

${ }^{49}$ Terry, GM (Miller: 1818), Act 1, Scene 1, p. 7.

${ }^{50}$ Terry, GM (Miller: 1818), Act 1, Scene 1, p. 10.

${ }^{51}$ Terry, GM (Miller: 1818), Act 3, Scene 1, p. 52.

${ }^{52}$ W. Oxberry, 'Introductory Remarks' to Guy Mannering by D. Terry, ed. by W. Oxberry (London: Simpkin and Marshall, 1820), p. i.

${ }^{53}$ Bolton, p. 56. 
${ }^{54}$ Terry, GM (Miller 1818), p. 5; Terry, Guy Mannering (London: Hodgson, 1822), p. 4.

55 Terry, 1818, p. 39.

${ }^{56}$ Hodgson, p. 15.

${ }^{57}$ William Hazlitt, 'The St James's Chronicle - The Morning Chronicle - The Times

- The New Times - The Courier, \&c. - Cobbett's Weekly Journal - The Examiner-

The Observer - The Gentleman's Magazine - The New Monthly Magazine - The

London, \&c. \&c.' ('The Periodical Press'), in: The Edinburgh Review 38, May 1823, 349-378, p.351.

58 Jeffrey Cox and Michael Gamer, 'Introduction' in The Broadview Anthology of

Romantic Drama, ed. Jeffrey Cox and Michael Gamer (Orchard Park, NY:

Broadview, 2003), p. xvii.

${ }^{59}$ Ina Ferris, The Achievement of Literary Authority; Gender, History and the

Waverley Novels (Ithaca: Cornell University Press, 1991), p. 30.

${ }^{60}$ The Quarterly Review January 1815, pp. 501-9, p. 507. Attrib. J. W. Croker.

${ }^{61}$ In James Hogg's The Private Memoirs and Confessions of a Justified Sinner the

Scottish peasantry associate Oxford University with magic and astrology, but

reviewers are clearly unaware of this association: 'They had some crude conceptions

that nothing was taught at Oxford but the black arts, which ridiculous idea prevailed

over all the south of Scotland.' James Hogg, The Private Memoirs and Confessions of

a Justified Sinner, ed. by John Carey (Oxford: Oxford University Press, 1969), p. 230.

${ }^{62}$ The Scots Magazine, August 1815, pp. 608-14, p. 609. The Scottish reviewer

emphasizes the historical nature of the plot, emphasizing the distance that English

reviewers stress in their focus on geography.

${ }^{63}$ The Critical Review, 600.3, June 1815, p. 601.

64 'Guy Mannering; or the Astrologer. By the Author of Waverley', The Scots

Magazine, August 1815, pp. 608-14, p. 609.

65 'Guy Mannering; or, the Astrologer. By the Author of Waverley', The British Critic, April 1815, pp. 399-409, p. 408.

${ }^{66}$ Bautz, The Reception of Jane Austen and Walter Scott, pp. 7-13.

67 'Guy Mannering; or, the Astrologer. By the Author of Waverley' The Augustan Review, July 1815, pp. 228-33, p. 231.

68 The Morning Post, $14^{\text {th }}$ July 1821, p.1. All newspapers and periodicals cited below accessed through: Nineteenth-century UK periodicals; Nineteenth-century British Library Newspapers, British Periodicals, The Times Digital Archive [all accessed May-July and December 2016].

${ }^{69}$ The Morning Post, $10^{\text {th }}$ September 1818, p.1.

${ }^{70}$ The Times, $13^{\text {th }}$ March 1816, p. 3.

${ }^{71}$ The Times, $13^{\text {th }}$ March 1816, p. 3.

${ }^{72}$ The European Magazine and London Review, 69, April 1816, pp. 334-40.

${ }^{73}$ Theatrical Inquisitor and Monthly Mirror, June 1816, pp. 440-42.

${ }^{74}$ Theatrical Inquisitor and Monthly Mirror, March 1816, pp. 228-32.

${ }^{75}$ The New Monthly Magazine and Universal Register, April 1816, pp. 250-52.

${ }^{76}$ Theatrical Inquisitor and Monthly Mirror, March 1816, pp. 228-32.

${ }^{77}$ The Literary Chronicle and Weekly Review, 18 December 1819, pp. 494-95.

${ }^{78}$ The Literary Chronicle and Weekly Review, 16 October 1819, p. 351.

${ }^{79}$ Commented on for example in The Times, 3 December 1817, p. 2; The Times, 18

September 1819, p. 2; The Morning Post, 19 September 1820 ('Braham was Braham rapturously applauded as ever in all his songs. That of "Scots wha hae wi' Wallace 
bled" he was obliged to sing three times...'), p.1; The Literary Chronicle and Weekly Review, 22 May 1822, p. 351.

${ }^{80}$ The Observer, 6 May 1822, p. 4.

${ }^{81}$ The Ladies' Monthly Museum, (November 1818), p. 285 and Theatrical Inquisitor and Monthly Mirror, 11 (September 1817), pp. 227-30, p. 229 respectively.

${ }^{82}$ The Ladies' Monthly Museum, (October 1819), p. 227.

${ }^{83}$ Theatrical Inquisitor and Monthly Mirror, 11 (September 1817), p. 229.

${ }^{84}$ Observer, 11 October 1819, p. 3.

${ }^{85}$ Judith Pascoe, Romantic Theatricality: Gender, Poetry, and Spectatorship (Ithaca: Cornell University Press, 1997), p. 15.

86 'Bishop's National Operas', The Athenaeum, 18 April 1874, p. 536.

${ }^{87}$ La Belle Assemblee, Vol 15, No. 95, March 1817, p.99.

${ }^{88}$ Ladies' Monthly Museum, 1 November 1818, p. 285.

${ }^{89}$ Interestingly, Terry as an actor is also described as 'chaste', so both as an actor and as a dramatist he is deemed unexceptionable. ('Memoir of the late Mr. Terry', in:

Dramatic Magazine, August 1829, p. 189.)

${ }^{90}$ The Times, 3 December 1817.

91 The European Magazine and London Review, April 1816, pp. 334-40.

${ }^{92}$ Anastasia Nikopoulou, 'Historical Disruptions: The Walter Scott Melodramas', in Melodrama: The Cultural Emergence of a Genre, ed. by Michael Hays and Anastasia Nikopoulou (New York: St Martin's Press, 1999), pp. 121-46.

${ }^{93}$ I am grateful to Susan Oliver and James Gregory for comments on this article. 